\title{
Using an artificial life simulation to enhance reflective critical thinking among student teachers
}

Byron Bunt ${ }^{1 *}$ and Grantt Gouws ${ }^{2}$

\author{
* Correspondence: 20172672@nwu. \\ ac.za \\ ${ }^{1}$ School of Commerce and Social \\ Studies in Education, Faculty of \\ Education, North-West University, \\ Vanderbijlpark, South Africa \\ Full list of author information is \\ available at the end of the article
}

\begin{abstract}
This paper presents a methodology for developing critical reflection among student teachers by using a novel artificial life simulation called Creatures. The paper is a report of an initial investigation that connects some theory to the affordances of a particular video game, and is a conceptual paper. In this paper, the various theories and concepts central to the methodology is outlined, and ultimately be combined and explored in depth. The game Creatures is also explored for its potential use as a reflective teaching tool. The actual methodology is then outlined for future research using this approach, ultimately concluding with tentative hypotheses regarding the significance of using artificial life for teacher education. Based on our combined experience in a higher education context lecturing education modules, student teachers do not critically reflect on their practice sufficiently and especially on the impact that their teaching will have on learners in the future. The Creatures simulation offers a viable solution to this problem, in which artificial creatures called Norns can be interacted with and taught important language and behavioral skills. In so doing, the student teachers who play the simulation may have a non-invasive manner in which to experience firsthand how their decisions may impact on future learning, and to reflect upon it using critical reflection.
\end{abstract}

Keywords: Critical reflection, Artificial life simulation, Creatures video game, Metacognition, Dispositions

\section{Introduction}

According to Walkington, Christensen, and Kock (2001), teacher education at university level requires student teachers to reflect on their practices and to adjust their teaching and assessment accordingly. However, through years of observation and lecturing student teachers, it has become apparent that these students do not only not reflect on their learning, but they do not reflect on their teaching during the practicum component of their training at schools (Howard, 2003). The problem of student teachers not reflecting and self-evaluating their practice leads to complacency and egocentric beliefs surrounding their abilities to teach, which could be linked to Lortie's apprenticeship of observation (Borg, 2004). The authors argue that reflective practice,

(c) The Author(s). 2020 Open Access This article is licensed under a Creative Commons Attribution 4.0 International License, which permits use, sharing, adaptation, distribution and reproduction in any medium or format, as long as you give appropriate credit to the original author(s) and the source, provide a link to the Creative Commons licence, and indicate if changes were made. The images or other third party material in this article are included in the article's Creative Commons licence, unless indicated otherwise in a credit line to the material. If material is not included in the article's Creative Commons licence and your intended use is not permitted by statutory regulation or exceeds the permitted use, you will need to obtain permission directly from the copyright holder. To view a copy of this licence, visit http://creativecommons.org/licenses/by/4.0/. 
although espoused in current assignments and portfolio requirements, are not effectively being implemented, and that a revolutionary new reflective strategy needs to be implemented, that will inculcate a natural, progressive, and reflective disposition within the student teachers (Harford \& MacRuairc, 2008; Tillema, 2000).

To that effect, a proposed framework will be discussed in this paper, with the intent of making use of an artificial life simulation called Creatures, which will have reflective activity imbedded within, in order for student teachers to reflect upon their actions. The authors are aware of several technological simulations that can be used to further develop reflective teaching, but the Creatures video game was specifically chosen, as it is essentially fun to play and was released with the intent of being played as a game and not as a serious simulation. The idea is that if students are playing this game, they may tangentially pick up the necessary reflection skills as they are engaged in gameplay.

\section{Theoretical/conceptual framework}

The main concepts central to this paper are cognitive and metacognitive skills, dispositions, critical reflection, game based learning and artificial life simulations. The next section pertains to the cognitive and meta-cognitive skills.

\section{Cognitive and meta-cognitive skills}

According to Facione (1990, 2000), Reynolds (2011), and Stupnisky, Renaud, Daniels, Haynes, and Perry (2008), the core critical thinking skills comprise observation, interpretation, analysis, inference, evaluation, explanation, and metacognition. As stated by Reynolds (2011), an individual or group engaged in robust critical thinking gives due deliberation to establish for instance:

- Evidence through reality.

- Background skills to separate a problem from a situation.

- Applicable criteria for making sound judgments.

- Appropriate methods or strategies for making a judgment.

- Valid theoretical constructs for understanding a problem and the question at hand.

In his Delphi study intended at reaching agreement concerning critical thinking, Facione $(1990,2009)$ discovered that experts in the field of critical thinking regard the subsequent cognitive and meta-cognitive skills as relating to critical thinking:

\section{Cognitive skills}

Inference

The ability to draw reasonable conclusions flowing from given information that can include opinions and judgements (Chartrand \& Rose, 2008; Facione, 2009). In order to draw inferences one needs to possess the ability to question information.

\section{Evaluation}

Judging the authenticity and credibility of information, and to establish if information that is provided is supportive of conclusions being made. Evaluation also means to be 
able to assess the logical strength of an inferred relationship between different sets of information (Chartrand \& Rose, 2008; Facione, 2009; Woolfolk, 2010).

\section{Analysis}

Identifying relationships between different sets of information, by focusing on similarities and differences (Chartrand \& Rose, 2008; Facione, 2009).

\section{Interpretation}

Understanding and communicating the meaning of information, which involves the application of skills such as categorisation and decoding information. Interpretation, implies comprehension and expression of meaning in relation to experiences, situations, and information (Chartrand \& Rose, 2008; Facione, 2009).

Metacognition is "cognition about cognition", "thinking about thinking", "knowing about knowing", becoming "aware of one's awareness" and higher-order thinking skills. The term comes from the root word meta, meaning "beyond", or "on top of". Metacognition can take many forms; it includes knowledge about when and how to use particular strategies for learning or problem-solving. There are generally two components of metacognition: (1) knowledge about cognition and (2) regulation of cognition.

\section{Meta-cognitive skills}

\section{Self-regulation}

Questioning, correcting and validating one's own thinking, opinions and assumptions (reflection) (Bandura, 2015; Dignath \& Büttner, 2008). In essence, the practice of selfregulation, means checking up on one's ideas and thoughts in order to establish if one' ideas and thoughts are logical, justified, and in accordance with the task that one is involved in.

\section{Explanation}

Expressing the results of one's thinking and providing reasons for the way of thinking coherently (Facione, 2009).

Essential skills that are applied during critical thinking are logical reasoning skills (Halpern, 2003). According to Bjorklund (2005) and Hughes and Lavery (2015), these logical reasoning skills are used in almost every human activity such as problem solving, decision making, interpreting, and making inferences (Kompf \& Bond, 2001). These metacognitive skills will be beneficial for student teachers when they critically reflect on their actions while playing the Creatures video game. The ability to question, correct and validate one's own thinking and to express the results of one's thinking will be useful in this study, as the student teachers would be expected to do this when playing the game, and to reflect on how their decisions can impact on the Norns in the game. This will link with the students' own experiences with the game and how they perceive what they are doing in the game. These experiences would potentially lead to self-corrective operation, in order to adapt or make changes to the world that the Norns inhabit.

The following section discusses the various critical thinking dispositions that exist and that can be fostered among students. 


\section{Critical thinking dispositions}

In addition to cognitive and meta-cognitive skills, critical thinkers should also attain a level of maturity in their development of critical thinking, by acquiring certain critical thinking attitudes or dispositions in addition to the aforementioned set of skills (Davies, 2013; Dewey, 1933; Fahim \& Shakouri, 2012; Norris \& Ennis, 1989). It is not enough to teach students to perform thinking operations and tasks. They should also be disposed to carrying them out on their own, unasked (Ennis, 1987), thus requiring habitual dispositions, or behavioural traits displayed automatically without any prompting on the teacher's part. According to Ennis (1987), p. 25 these dispositions include:

- Seeking a clear statement of the thesis or question.

- Seeking reasons.

- Trying to be well informed.

- Using and mentioning trustworthy sources.

- Taking into account the entire situation.

- Trying to remain relevant to the main point.

- Keeping in mind the primary or basic concern.

- Looking for alternatives.

- Being open-minded.

- Taking a position (and changing a position) when the evidence and reasons are adequate to do so.

- Seeking as much accuracy as the subject allows.

- Dealing in an orderly manner with the parts of a complex whole.

- Using one's critical thinking abilities.

- Being sensitive to the feelings, level of knowledge, and degree of sophistication of others.

The dispositions mentioned by Ennis (1987) align well with the view of Facione (2000), p. 64, who defined human dispositions as “...a person's consistent internal motivation to act toward, or to respond to, persons, events, or circumstances in habitual, and yet potentially malleable, ways".

The seven critical thinking dispositions identified by Facione (2000), p. 64; 2009, p. 8 include:

\section{Truth-seeking}

A daring aspiration for the best knowledge, even if such knowledge fails to support or challenges one's preconceptions, beliefs or self-interests.

\section{Open-mindedness}

Acceptance of different views, and self-monitoring for likely subjectivity.

\section{Inquisitiveness}

Being inquisitive and enthusiastic to obtain knowledge and learn explanations even when the applications of the knowledge are not directly obvious. 


\section{Analyticity}

Demanding the application of reason and evidence, attentive to challenging situations, disposed to expect consequences.

\section{Systematicity}

Appreciating administration, attention and thoroughness to approach problems of all levels of complexity.

\section{Critical thinking self-confidence}

Trusting of one's own reasoning skills and seeing oneself as a good thinker.

\section{Cognitive maturity}

Being discrete in making, suspending, or reviewing judgment, displaying an awareness that multiple solutions can be acceptable, and appreciating the need to reach closure even in the absence of complete knowledge.

Dispositions are also referred to as habits of mind that define a person's predisposition toward critical thinking, and comprise a willingness to follow reason, a logical approach to problem solving, curiosity, impartiality, and confidence in reasoning (Costa, 2009).

Costa and Kallick (2005), p. 4, indicate that habits of mind are "an identified set of 16 problem solving, life-related skills, necessary to effectively operate in society and promote strategic reasoning, insightfulness, perseverance, creativity and craftsmanship". The understanding and application of these 16 habits of mind function to afford the individual with skills to work through actual life situations that prepare that person to react using awareness (cues), thought, and intentional strategy in order to gain a positive outcome (Costa \& Kallick, 2005). The following section provides an overview of the 16 habits of mind in more depth.

\section{Persisting}

Remaining focused on the task and following through in order to complete a task.

\section{Managing impulsivity}

Taking the time to decide upon options; thinking prior to speaking or acting; staying composed when stressed or challenged; being sympathetic and considerate of others; and advancing carefully.

\section{Listening with understanding and empathy}

Paying attention to and not ignoring another person's opinions, emotion and thoughts; striving to put oneself in another person's shoes; expressing verbally to others when one can relate to what they are conveying; and holding thoughts at a distance in order to respect another person's point of view and feelings.

\section{Thinking flexibly}

Being capable of changing a viewpoint; considering the contributions of others; creating alternatives; and considering options. 


\section{Thinking about thinking (metacognition)}

Being mindful of individual thoughts, emotions, goals and actions; knowing what one does and says has an emotional impact on others; and being eager to reflect on the effect of choices on oneself and others.

\section{Striving for accuracy}

Determining if there are errors; measuring at least twice; and cultivating a need for precision, commitment and expertise.

\section{Questioning and posing problems}

Asking oneself, "How do I know this?"; cultivating a questioning outlook; contemplating on what information is required; selecting strategies to obtain that information; and contemplating on the impediments that are necessary to resolve.

\section{Applying past knowledge to new situations}

Practicing what is learned; contemplating on prior knowledge and experience; and applying knowledge outside of the context in which it was acquired.

Thinking and communicating with clarity and precision

Endeavouring to be clear when communicating and writing; attempting to be precise when communicating; evading generalisations, misrepresentations, simplifications and omissions when communicating, and writing.

\section{Gathering data through all senses}

Taking the time to observe what one sees; listening to what one hears; taking note of what one smells; tasting what one eats; and feeling what one is touching.

\section{Creating, imagining, innovating}

Thinking about how something might be done differently from the norm; suggesting novel ideas; endeavouring for innovation; and considering novel suggestions others might make.

\section{Responding with wonderment and awe}

Being intrigued by the world's beauty, nature's power and vastness of the universe; having regard for what is awe-inspiring and can touch one's heart; and opening up to the little and big surprises in life.

\section{Taking responsible risks}

Preparing to try something different; contemplating doing things that are safe and rational even though it may be new; and facing the fear of making errors.

\section{Finding humour}

Being eager to laugh appropriately; searching for the whimsical, silly, sarcastic and unexpected in life; and laughing at oneself when one can. 


\section{Thinking interdependently}

Being eager to engage with others and openly seek their input and viewpoint; accepting the decisions that others make even though one might differ slightly; and being disposed to learn from others in mutual circumstances.

\section{Remaining open to continuous learning}

Being receptive to novel experiences in order to learn; being grateful and modest enough to acknowledge when not knowing something; and gladly accepting new information on all subjects.

The critical thinking dispositions as espoused by Facione (2000) link well with Costa and Kallick's (2005) extensive list of 16 habits of mind, as both describe an individual's tendency or inclination to reason or think in a critical manner. Both refer to actions or thoughts that occur on a regular basis. Dispositions enhance the quality of thinking, and are therefore necessary, in order for one to recognise when critical thinking skills are needed. Moreover, a willing and mental effort is required to apply critical thinking skills (Facione, 2011; Profetto-McGrath (2003).

From the previous discussion, it is clear that in order to achieve the goal of reflective critical thinking, students require the correct dispositional habits in order to be more pre-disposed towards thinking in a reflective manner. These habits could be inculcated through the use of the Creatures video game. If the students are motivated to play the game, they may become predisposed to using these habits and internalizing them. Major habits that would play a role when playing the Creatures video game include applying past knowledge to new situations, where the player will need to take pre-existing knowledge about how Norns can interact with certain objects and try to adapt to new objects, as well as gathering data through all senses. The player would need to interpret the world that the Norns exist in to find out what can be interacted with and what dangers lurk within their world. The next section details the nature of critical reflection.

\section{Critical reflection}

Critical reflection can be understood as a reasoning procedure to create meaning of an experience (Howard, 2003). Critical reflection can be descriptive, logical, and critical, and can be articulated in numerous manners such as in written form, orally, or as an artistic expression (Yang, 2009). In brief, this process can enhance depth and breadth to an experience and constructs links between course content and the experience (Mezirow, 1998).

Frequently, a reflection activity is directed by a set of written stimuli (Howard, 2003). A best practice for critical reflection is that students ought to react to prompts before, during, and after their experience; consequently, the prompts should be attuned to equal the timing of the reflection (Yang, 2009). Critical reflection can be incorporated into any type of experiential learning activity - inside the classroom or outside the classroom (Mezirow, 1998).

It is essential to comprehend what critical reflection is not. It is not a reading assignment, it is not an activity summary, and it is not an emotional channel without other dimensions of experience described and analysed (Mezirow, 1998; Yang, 2009). Critical reflection should be cautiously considered by the instructor to generate and document student learning before, during, and after the experience (Howard, 2003). 
Four steps ought to be considered when utilizing critical reflection:

1. Identify the student learning outcomes related to the experience. What do you expect students to gain as a result of this activity? Understand multiple points of view? Be able to propose solutions to a problem? (Howard, 2003)

2. Once you identify the outcomes, then you can design the reflection activities to best achieve the outcomes. Remember, that critical reflection is a continuous process (Howard, 2003).

3. Engage students in critical reflection before, during, and after the experience (Howard, 2003).

4. Assess their learning. A rubric that outlines the criteria for evaluation and levels of performance for each criterion can be useful for grading reflection products and providing detailed feedback to students (Howard, 2003; Yang, 2009).

All four of these previous steps will be conducted in the study. All student teacher participants who play the Creatures video game will be given specific outcomes that they will need to reach, such as being able to reflect on their actions. Next, the researchers would give a set list of questions which would form step 2, which take the form of a reflective activity. Step 3 will be carried out before the Creatures video game is played, during, as well as after. The researchers will develop a scoring rubric for these reflections in order to assist them in grading the feedback given.

Dewey (1933) was among the first to identify reflection as a specialised form of thinking (Finlay, 2008). He considered reflection to stem from doubt, hesitation or perplexity related to a directly experienced situation. For him, this prompted purposeful inquiry and problem resolution (Sinclair, 1998). Dewey also argued that reflective thinking moved people away from routine thinking/action (guided by tradition or external authority) towards reflective action (involving careful, critical consideration of taken-for-granted knowledge) (Finlay, 2008). This way of conceptualising reflection crucially starts with experience and stresses how we learn from 'doing', i.e. practice. Specifically, Dewey argued that we 'think the problem out' towards formulating hypotheses in trial and error reflective situations and then use these to plan action, testing out our ideas (Finlay, 2008).

Dewey's ideas provided a basis for the concept of 'reflective practice' which gained influence with the arrival of Schön (1983) 'The reflective practitioner: how professionals think in action'. In this seminal work, Schon identified ways in which professionals could become aware of their implicit knowledge and learn from their experience. His main concern was to facilitate the development of reflective practitioners rather than describe the process of reflection per se. However, one of his most important and enduring contributions was to identify two types of reflection: reflection-on-action (after-the-event thinking) and reflection-in-action (thinking while doing).

In the case of reflection-on-action, professionals are understood consciously to review, describe, analyse and evaluate their past practice with a view to gaining insight to improve future practice (Finlay, 2008). With reflection-in-action, professionals are seen as examining their experiences and responses as they occur. In both types of reflection, professionals aim to connect with their feelings and attend to relevant theory (Finlay, 2008). They seek to build new understandings to shape their action in the unfolding situation. In Schon's words: 
"The practitioner allows himself to experience surprise, puzzlement, or confusion in a situation which he finds uncertain or unique. He reflects on the phenomenon before him, and on the prior understandings which have been implicit in his behaviour. He carries out an experiment which serves to generate both a new understanding of the phenomenon and a change in the situation" (Schön, 1983, p.68).

From the previous discussion, it is clear that critical reflection is a key skill that students should possess. The Creatures video game strategy that would be implemented would allow for students to reflect in action, that is to say they will reflect while playing the game, and how their thinking and actions are influencing the Norns and how they are developing. However, reflection on practice will be carried out as well at the end of the Creatures video game intervention, in which student teachers would transfer the reflection in action that was previously carried out in the game into their classrooms when they go out for their practicum period. In order to obtain this reflective goal, the authors wish to move to a discussion on how we envisage to attain this goal using game based learning, and more specifically, artificial life simulations.

\section{Transfer of learning theory}

Transfer of learning takes place when students see the value of applying knowledge or skills acquired previously and stored in their memories, to other situations. Research indicates that learning transfer is infrequent and that it occurs most commonly when instruction is "... cued, primed, and guided..." (Bransford, Brown, Cocking, Pellegrino, \& Donovan, 2000, p. 324).

Various hypotheses and definitions have been advanced for transfer of learning. Firstly, it is speculated that different types of transfer exist, namely near transfer (the application of skill to solve a novel problem in a similar context), and far transfer (the presentation of skill to solve novel problems presented in a dissimilar context) (Perkins \& Salomon, 1992).

Secondly, Perkins and Salomon (1992) and Schwartz, Bransford, and Sears (2005) propose that positive transfer happens in circumstances where learning supports original problem solving, and negative transfer happens when previous learning constrains performance on decidedly connected tasks. Thirdly, Schwartz et al. (2005) propose that transferring knowledge into a situation may differ from transferring knowledge out to a situation as a means to reconcile findings that transfer may both be frequent and challenging to promote.

A significant and long research history has also endeavoured to elucidate the circumstances under which transfer of learning might happen. Early research by Ruger (1910) for example found that, the "level of attention", "attitudes", "method of attack" (or method for tackling a problem), a "search for new points of view", "a careful testing of hypothesis" and "generalization" were all valuable approaches for promoting transfer (Ruger, 1910, p. 15). To encourage transfer through teaching, Perkins and Salomon (1992), p. 6457 recommend aligning ("hugging") instruction with practice and assessment, and "bridging", or encouraging students to reflect on past experiences or make connections between prior knowledge and current content for effective transfer to occur.

There is disagreement among researchers regarding the transferability of critical thinking skills learned in one context, to new contexts, domains, and disciplines. Some researchers (Halpern, 1998; Willingham, 2008), have a tendency to agree that 


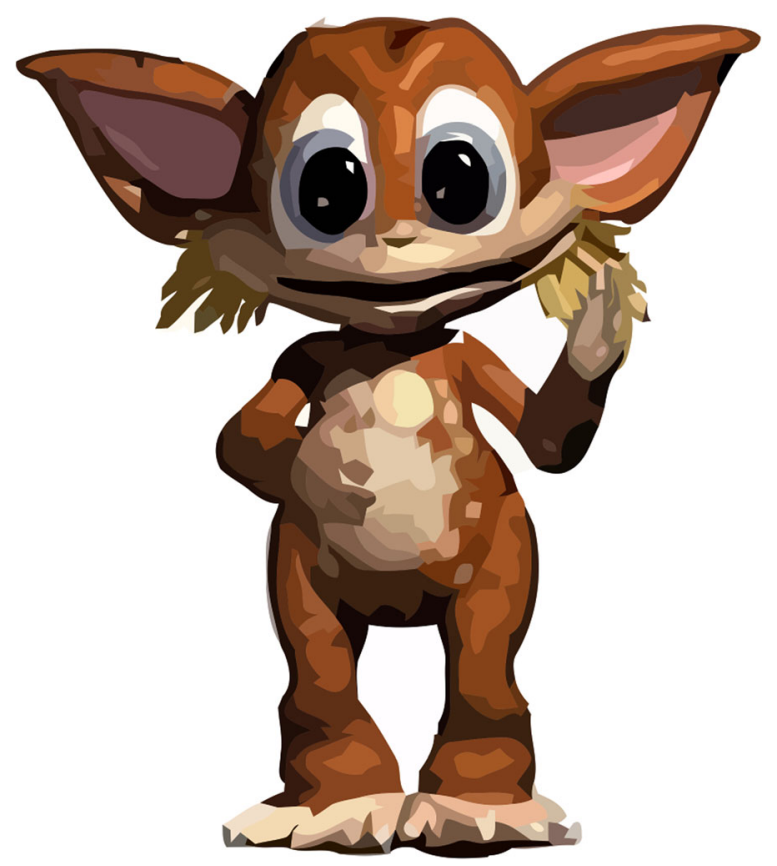

Fig. 1 A Norn in the Creatures video game

transferability is unlikely to happen unless students are instructed to explicitly transfer these skills. Students therefore need to be offered opportunities to employ critical thinking skills and abilities in a variety of contexts and subject areas. Furthermore, instruction should accentuate executive functioning or meta-cognitive skills, such as setting goals, planning, and monitoring progress toward goals (Kennedy, 1991). Thirdly, students should be exposed to deep problem structure, because most students' thinking tends to concentrate on the surface structure of problems, or the superficial aspects of tasks (Halpern, 1998; Willingham, 2008).

Hummel and Holyoak (cited in Halpern, 1998, p. 181) highlight the importance of structure sensitivity for the transferability of critical thinking skills. They define structure sensitivity as the ability to "code and manipulate relational knowledge." The purpose of structure training is to encourage and allow students to identify a specific problem structure each time they come across it, whether it is presented in math, science, or social studies, and that they then utilise suitable strategies to solve the problems. Structure training entails issuing practice in diverse environments and settings. Halpern (1998) points out that the use of real-world learning activities helps to stimulate the transfer of critical thinking skills. Brown (1990) reasons that domain-specific knowledge may be needed for young children to effectively transfer skills to new problems that display the same deep structure. She commented, "We conclude that even young children show insightful learning and transfer on the basis of deep structural principles, rather than mere reliance on salient perceptual features, when they have access to the requisite domain-specific knowledge to mediate that learning" (Brown, 1990, p. 130). Thus, teaching for transfer may also entail providing adequate instruction on relevant background information. This will be carried out with any student teachers playing the Creatures video game, as the game mechanics and controls will need to be taught to them first, as well as how they should be reflecting while playing. 
Table 1 Object categories in the Creatures game

\begin{tabular}{l|l}
\hline \multicolumn{1}{c|}{ Suggested Category Name } & \multicolumn{1}{c}{ Objects within that category } \\
\hline Food & Carrots, Cheese, Honey, Lemons \\
\hline Drink & Coffee, Hootch (small green cups) \\
\hline Button & Call button for lift \\
\hline Lift & Green lift button \\
\hline Mover & All vehicles including teleporter \\
\hline Toys (Small Toys) & Ball, Spinning top, Radio \\
\hline Bigtoys (Large Toys) & $\begin{array}{l}\text { Jack-in-a-box, Robot, } \\
\end{array}$ \\
\hline Plants & Flipper-D-jib-it (Helicopter springy thing) \\
\hline Weeds & All the plants that make Norns well \\
\hline Grendel & All the plants that make Norns ill \\
\hline Norn & The Grendel (Big nasty green monster) \\
\hline Music & Other Norns (all in same group) \\
\hline Animals & Harp, Trumpet, Drum, Jukebox \\
\hline Fire & Birds, Jellyfish, Sea Horses, Bees, Goldfish \\
\hline Shower & Kitchen Fire \\
\hline Water & Kitchen Clock, Shower \\
\hline Slide & Waterfall \\
\hline Bang & Slide projector and screen \\
\hline Vender & Cannon in Lighthouse \\
\hline & The Hives, The Still, The Carrot Vender \\
\hline
\end{tabular}

From this previous discussion on critical reflection, it is important to understand the specific strategy or methodology that will be used in implementing this reflective practice. The envisaged strategy will use the Creatures video game, which falls under the strategy of game-based learning.

\section{Game-based learning}

As this paper addresses using a video game to develop metacognitive reflective thinking among student teachers, it is important to discuss the theory of game-based learning and serious games.

It is crucial to understand that while all serious games incorporate game-based learning, not all game-based learning can be called serious games. According to Djaouti, Alvarez, and Jessel (2011), a serious game or applied game is a game intended for a principal purpose other than pure entertainment. The "serious" adjective is usually added to denote to video games used by industries like defence, education, scientific exploration, health care, emergency management, city planning, engineering, and politics (Djaouti et al., 2011). Serious games can be viewed as a sub-genre of serious storytelling (Lugmayr et al., 2017, p. 15707), where storytelling is applied "outside the context of entertainment, where the narration develops as an arrangement of patterns impressive in quality ... and is part of a thoughtful progress" (Lugmayr et al., 2017, p. 15707). The aforementioned description highlights the features of simulation, usually containing flight simulation and medical simulation, but also highlights the additional pedagogical value of fun and competition.

Game-based learning denotes to the appropriating of definite gaming principles and relating them to real-life settings to engross users (Trybus, 2010). The motivational psychology involved in game based learning allows students to engage with educational 


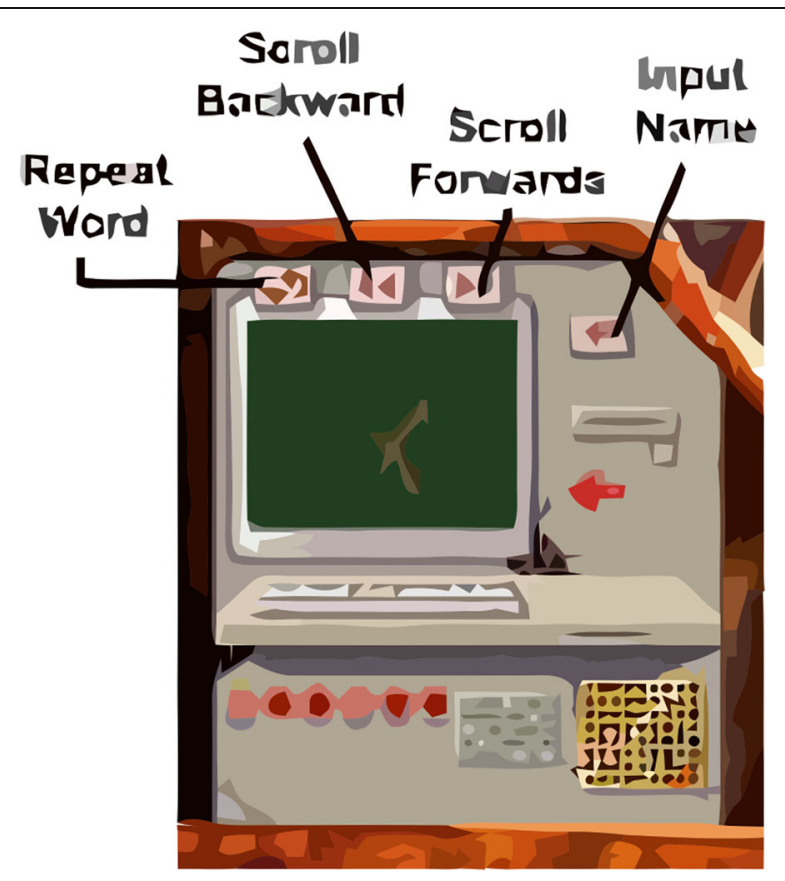

Fig. 2 The computer in the Creatures video game

materials in an active and enthusiastic manner (Pho \& Dinscore, 2015). Game-based learning does not only involve games for students to play, it also plans for learning activities that can sequentially introduce concepts, and facilitate users towards an end objective. Old-fashioned games can integrate competition, points, incentives, and feedback loops. According to Pho and Dinscore (2015), game-based learning has become increasingly popular in higher education as a way to engage students in learning.

The following section focuses specifically on artificial life simulations and how they function.

\section{Artificial life simulation and neural networks}

Artificial life (often abbreviated ALife or A-Life) is an area of scholarship where researchers scrutinize systems connected to natural life, its processes, and its development, through the usage of simulations with computer models, robotics, and biochemistry (Bedau et al., 2000). The discipline was coined by Christopher Langton, an American theoretical biologist, in 1986 (Langton, 1997). There are three main types of Alife, labelled for their methodologies: soft (Kadleček \& Nahodil, 2001), from software; hard (Kirby, 2002), from hardware; and wet, from biochemistry. Artificial life researchers study traditional biology by attempting to reconstruct features of biological occurrences (Grand, 2005).

Artificial neural networks (ANN) or connectionist systems are computing systems that are inspired by, but not the same as, biological neural networks that make up animal brains (Langton, 1997). Such systems "learn" to do things by looking at examples, usually devoid of programming with task-specific rules (Curran \& O'Riordan, 2003). For instance, in image recognition, they may learn to classify images that comprise of cats by examining example images that have been physically labeled as "cat" or "no cat" and utilizing the findings to identify cats in other images (Grand, 2005). They do this 
Table 2 Concepts that can be taught to a Norn

\begin{tabular}{|c|c|c|c|c|c|}
\hline $\begin{array}{l}\text { Concept } \\
\text { Icon }\end{array}$ & $\begin{array}{l}\text { Default } \\
\text { Word }\end{array}$ & Purpose & $\begin{array}{l}\text { Concept } \\
\text { Icon }\end{array}$ & $\begin{array}{l}\text { Default } \\
\text { Word }\end{array}$ & Purpose \\
\hline leep & Sleep & Asks a Norn to sleep & come & Come & $\begin{array}{c}\text { Asks Norn to come towards } \\
\text { the hand }\end{array}$ \\
\hline 8 & Look & $\begin{array}{c}\text { Tells Norn to look at } \\
\text { the object closest to } \\
\text { your hand }\end{array}$ & run & Run & $\begin{array}{c}\text { Tells Nom to run away very } \\
\text { fast }\end{array}$ \\
\hline Ish & Push & $\begin{array}{l}\text { Tells Nom to activate } \\
\text { and object, or push it }\end{array}$ & get & Get & $\begin{array}{c}\text { Tells Norn to pick up an } \\
\text { object }\end{array}$ \\
\hline g & Pull & $\begin{array}{l}\text { Tells Nom to activate } \\
\text { an object, or pull it }\end{array}$ & drop & Drop & Tells Norn to drop an object \\
\hline 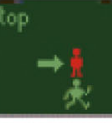 & Stop & $\begin{array}{l}\text { Tells Norn to stop } \\
\text { what it is doing }\end{array}$ & & What & $\begin{array}{l}\text { Asks Norn what it thinks it } \\
\text { is doing }\end{array}$ \\
\hline$\stackrel{6}{g}$ & Yes & $\begin{array}{l}\text { Reinforces an action } \\
\text { that the Norn has } \\
\text { performed correctly }\end{array}$ & right & Right & $\begin{array}{c}\text { Tells Norn to walk to the } \\
\text { right }\end{array}$ \\
\hline$\Omega_{0}^{\circ}$ & No & $\begin{array}{c}\text { Punishes a Norn when } \\
\text { it has done something } \\
\text { wrong }\end{array}$ & left & Left & $\begin{array}{c}\text { Tells Norn to walk to the } \\
\text { left }\end{array}$ \\
\hline
\end{tabular}

deprived of any previous knowledge of cats, for instance, that they have fur, tails, whiskers and cat-like faces. In its place, they spontaneously produce identifying characteristics from the examples that they process (James, Scogings, \& Hawick, 2004).

An ANN is founded on a group of connected units or nodes named artificial neurons, which roughly represent the neurons in a biological brain (Kadleček \& Nahodil, 2001). Each connection, similar to the synapses in a biological brain, can send a signal to other neurons (Bedau et al., 2000). An artificial neuron that receives a signal then processes it and can signal neurons connected to it (Kirby, 2002).

In ANN applications, the "signal" at a connection is a real number, and the output of individual neurons is computed by some non-linear function of the sum of its inputs (James et al., 2004). The connections are called edges. Neurons and edges characteristically have a mass that regulates as learning continues (Curran \& O'Riordan, 2003). The mass grows or declines the strength of the signal at a connection (Grand, 2005). Neurons may have a threshold such that a signal is directed only if the collective signal crosses that threshold (Langton, 1997). Normally, neurons are combined into layers. Alternate layers can perform alternate transformations on their inputs. Signals travel from the first layer (the input layer), to the last layer (the output layer), possibly after traversing the layers multiple times (Bedau et al., 2000).

The original goal of the ANN approach was to solve problems in the same way that a human brain would (Curran \& O'Riordan, 2003). However, over time, attention moved 
to performing specific tasks, leading to deviations from biology (Langton, 1997). ANNs have been used on a variety of tasks, including computer vision, speech recognition, machine translation, social network filtering, playing board and video games and medical diagnosis (Langton, 1997). This links with the aim of this investigation, as the Creatures video game would serve the function of a specific task, namely to support the development of student teacher critical reflection.

From the previous discussion, it is apparent that artificial life simulations attempt to understand evolutionary processes such as cognition utilizing computer technology (Grand, 2005). One such successful simulation will now be elaborated upon, known as Creatures.

\section{Creatures video game}

Creatures is an artificial life (Alife) computer program series, created in the mid-1990s by English computer scientist Steve Grand while employed at the Cambridge video games developer Millennium Interactive (Grand, 2003). Gameplay centers on nurturing extra-terrestrial creatures known as Norns, teaching them to survive, assisting them to explore their world, protecting them against other species, and breeding them (Grand \& Cliff, 1998). Words can be taught to creatures by a learning computer (for verbs) or by repeating the name of the object while the creature is looking at it (Grand, 2003). After a creature comprehends language, the player can teach their creature by typing in instructions, which the creature might choose to act upon (Grand \& Cliff, 1998). A comprehensive life cycle is demonstrated for the creatures - childhood, adolescence, adulthood, and senescence, each with their own specific requirements (Grand, 2003). The gameplay is intended to nurture an emotional connection among the player and their creatures. Rather than taking a scripted style, Creatures series games were driven by comprehensive biological and neurological simulation and their unpredicted results (Kember, 2003). There were six major Creatures releases from Creature Labs. Between 1996 and 2001, there were three principal games released, the Docking Station add-on (generally referenced as a separate game) and two children's games, and there were three games created for console systems (Grand, 2003). A sequel named Creatures Online was in development, with the artificial life technology from Creatures 3 and Docking Station updated to a 3D environment (Grand, 2004).

\section{Norns}

Norns (Cyberlifogenis cutis) are a species of creature, made by the Shee to amuse them and serve tea and biscuits (Grand \& Cliff, 1998; Fig. 1). They were genetically engineered on the disc-shaped planet Albia. Several were left behind there as the Shee took off in their spaceship, the Ark (though they did take a few of them with them). They are endearing and innocent creatures, who require some attention to survive, though some breeds are more adept in living in the wild (Grand \& Cliff, 1998).

Norns are the main Alife appeal of the games in the Creatures series (Grand, 2005). They compete (to an extent) amongst one another, and with the other species currently in Albia and on the Ark: Ettins and Grendels (Grand \& Cliff, 1998). Players can choose to help them survive, typically by active administration of their surroundings and the adding of numerous helper agents (Table 1), or leave them to fend for themselves over protracted periods of time in feral runs (Grand, 2003). Some go even further in their 
"testing" of norns, which others refer to as norn torture, which brings up several ethical questions as to whether torturing norns is morally wrong (Grand \& Cliff, 1998).

\section{Teaching the Norns}

The computer (Fig. 2) is one of the most important objects in the game (Grand, 2003). It teaches Norns the fourteen concepts of language used to guide and influence a Norn's life (Grand \& Cliff, 1998). Once a Norn is standing next to the computer, the player needs to press the left button at the top of the computer to repeat the current concept on screen (Table 2). The Norn will attempt to speak the word that the computer is trying to teach him/her. It is helpful to repeat the concept until the Norn says the word correctly (Grand \& Cliff, 1998). Once the Norn says the word correctly he/she will then know and understand what to do if you say the word to him (Grand, 2003).

The two arrow buttons will cycle the fourteen concepts to the left or right respectively. Repeat the process until the Norn has learnt all fourteen concepts very well (Grand, 2003). It is important to teach all of the Norns the concepts as soon as they are born (Grand \& Cliff, 1998). If left untaught, the other Norns in the world will teach the babies language, but it is possible that an adult Norn could learn baby language. The consequences of not teaching Norns language can lead to them not understanding the player's commands.

Once you have taught your Norn one or two of the concepts yourself he will most likely carry on learning if you leave him alone (Grand \& Cliff, 1998).

The following table describes all fourteen concepts that can be taught to a Norn via the computer.

The more times you repeat a concept on the computer screen the better the Norn will learn that concept (Grand \& Cliff, 1998). It is advised that once a concept is said correctly that you repeat it a further three or four times. This will radically reduce the possibility of adults learning baby talk and strengthen their ability to teach others (Grand, 2003).

\section{Objects within the game}

There are many objects to be found in Albia (Table 1). It is important that your Norn knows the names of all objects in the world to communicate properly (Grand, 2003). Once your Norn is able to distinguish different objects, you will be able to instruct him to operate them (Grand \& Cliff, 1998).

The following table illustrates the categories found in Creatures and the objects within those categories.

It is very important to note that all objects within Albia are categorized. There are approximately twenty different categories of objects (Grand \& Cliff, 1998). Once a Norn knows the name of one object he/she will associate the same name to all other objects within that group. It is also advisable to keep the names short to cut down on typing (Grand, 2003).

\section{Methodology: using creatures as an educational and reflective tool for student teachers}

The Creatures video game can be used to teach student teachers about specific learning theories. As has been mentioned previously, the Norns can be taught certain behavior using reinforcement and punishment by either tickling/slapping them, or by saying "yes" and "no". This links to the learning theory of behaviorism. Behaviourism views a 
student as fundamentally passive, reacting to environmental stimuli (Skinner, 2011). The student begins as a clean slate (i.e. tabula rasa) and behaviour is moulded through positive reinforcement or negative reinforcement (Watson, 2013). Together, positive reinforcement and negative reinforcement increase the possibility that the precursor behaviour will happen or not happen again. Learning is consequently defined as a change in behaviour in the student (Pavlov \& Anrep, 2003).

Within the behaviourist view of learning, the teacher is the central person in the classroom and takes complete control (Arends, 2004; Neisser, 2014). The student has limited occasions for evaluation or reflection within the learning process, and is merely told what is right or wrong, thus supporting a positivist realist approach to knowledge acquisition (South African Institute for Distance Education, 2012). In addition, a critical realist approach could also characterise behaviourism, which implies that knowledge is viewed as non-prescriptive and fallible (South African Institute for Distance Education, 2012). According to Arends (2004) and Neisser (2014) the conceptualisation of learning by means of a positivist realist approach could be regarded as insignificant, as the emphasis is on the product or outcome of learning without giving consideration to the internal thinking processes and emotions involved during the process to produce the learning outcome.

Another learning theory that can be demonstrated within the Creatures video game is constructivism, more precisely social constructivism. Constructivism postulates that learning is an active, constructive process, where learning takes place by doing and discovery (Ackermann, 2001; Killen, 2015; Kirschner, Sweller, \& Clark, 2006; Powell \& Kalina, 2009; Tobias \& Duffy, 2009. The student is an information builder and constructs knowledge out of experiences (Bächtold, 2013; Duffy \& Jonassen, 2013; Piaget, 2013; Tobias \& Duffy, 2009; Vygotsky, 1980). Social constructivism entails learning from others' experiences through modelling behaviour, as well as learning from the consequences of others' behaviour. This is true for Creatures, as the Norns can learn from each other, as they can teach each other language and the various categories of items. They can also learn from observing the consequences of other Norns' behaviour. If one Norn is being disciplined with a smack of the hand, if another Norn is watching, they will also learn that the particular behaviour is bad.

The benefit for using the Creatures video game as an educational tool for student teachers is invaluable. Instead of merely being lectured to about these learning theories, they can now see first-hand these theories being simulated without any negative consequences on real school learners. As they have direct control of what gets taught to their Norns and the consequences of their choices being simulated in real time, it can make for a powerful learning experience in terms of how learners learn in schools. This is where the reflection benefit will be most useful for student teachers.

\section{Conclusion}

It is envisioned that a study using this method would incorporate some form of selfreflection questionnaire or interview where the student teacher would need to critically comment on their actions and experiences with the Norns and relate it to the classroom. Over a period of time it would be interesting to measure the levels of critical reflection and to test whether improvement was noted among student teachers. This method could possibly also lead to the inculcation of specific habits of mind or critical thinking dispositions, such as metacognition, persistence and managing impulsivity. 


\section{Acknowledgments}

None.

\section{Authors' contributions}

Dr. Bunt gathered the literature on cognitive and metacognitive skills, critical thinking dispositions, critical reflection and game-based learning. Mr. Gouws obtained literature for Artificial life simulation and neural networks, Creatures video game as well as sections on the Norns and how to teach them. Dr. Bunt did the final layout of the article as well as the conclusion section. The author(s) read and approved the final manuscript.

\section{Authors' information}

Dr. Byron John Bunt is a lecturer in the Faculty of Education of the North-West University. He has been working in the field of teacher education for the past 10 years, and his research niche encompasses cognitive education, with a specific focus on developing student creative and critical thinking through the use of various teaching strategies and technology. He is a beginner researcher, and has published in the fields of history education and teacher education. $\mathrm{He}$ is the author of the chapter entitled Cognitive development strategies within the History classroom in the book Teaching and Learning History and Geography, published by Van Schaik in 2018. He has begun a scholarship of teaching and learning project which involves the use of a self-developed trading card game called Dogs of War, which will be used within his History classroom with the aim of developing the self-directed learning abilities of his students. Before lecturing, he worked as a teacher at General Smuts High School in Vereeniging, teaching Social Science and Technology.

Mr. Grantt Gouws is a junior lecturer in the Faculty of Education of the North-West University. He has been lecturing at the university since 2013 in the fields of curriculum studies and work-integrated learning. He obtained his B.Ed Honours degree in 2015. He is currently registering for a Master's degree in Education, which will focus on the development of teacher's metacognitive skills and reflection using technology and game-based learning. Before lecturing, Mr. Gouws was a teacher at Meyerton Primary School teaching Technology and Social Science.

\section{Funding}

This project will have no funding.

\section{Availability of data and materials}

All data will be made available once the research commences. Materials are also readily available, such as the Creatures game.

\section{Competing interests}

The authors declare that they have no competing interests.

\section{Author details}

${ }^{1}$ School of Commerce and Social Studies in Education, Faculty of Education, North-West University, Vanderbijlpark, South Africa. ${ }^{2}$ School of Professional Studies in Education, Faculty of Education, North-West University, Vanderbijpark, South Africa.

Received: 23 January 2020 Accepted: 18 March 2020

Published online: 15 April 2020

\section{References}

Ackermann, E. (2001). Piaget's constructivism, Papert's constructionism: What's the difference. Future of Learning Group Publication, 5(3), 438

Arends, R. I. (2004). Learning to teach (6th ed.). Boston: McGraw-Hill.

Bächtold, M. (2013). What do students "construct" according to constructivism in science education? Res. Sci. Educ., 43(6), $2477-2496$

Bandura, A. (2015). On deconstructing commentaries regarding alternative theories of self-regulation. J. Manag., 41(4), $1025-1044$. Bedau, M. A., McCaskill, J. S., Packard, N. H., Rasmussen, S., Adami, C., Green, D. G., et al. (2000). Open problems in artificial life. Artificial Life, 6(4), 363-376.

Bjorklund, D. F. (2005). Children's thinking: Cognitive development and individual differences (4th ed.). California: Thomson Wadsworth Borg, M. (2004). The apprenticeship of observation. ELT J., 58(3), 274-276.

Bransford, J., Brown, A., Cocking, R., Pellegrino, J., \& Donovan, M. (2000). How people learn: Brain, mind, experience, and school. In Committee on developments in the science of learning with additional material from the committee on learning research and educational practice, \& National Research Council. Washington, DC: The National Academies.

Brown, A. L. (1990). Domain-specific principles affect learning and transfer in children. Cogn. Sci., 14(1), 107-133.

Chartrand, J., \& Rose, M. (2008). The difference between good leaders and great leaders: How to assess for critical thinkers in hiring and development Retrieved from http://www.pearsonpsychcorp.com.au/userfiles/Good\%20and\%20Great\%20Leaders_Aus.pdf.

Costa, A., \& Kallick, B. (2005). Habits of mind. Victoria: Hawker Brownlow Education.

Costa, AL. (2009). Habits of mind across the curriculum. Practical and creative strategies for teachers. Alexandria, VA: Association for Supervision and Curriculum Development.

Curran, D., \& O'Riordan, C. (2003). Artificial life simulation using marker-based encoding.

Davies, M. (2013). Critical thinking and the disciplines reconsidered. High. Educ. Res. Dev., 32(4), 529-544.

Dewey, J. (1933). How we think: A restatement of the relation of reflective thinking to the educative process DC Heath.

Dignath, C., \& Büttner, G. (2008). Components of fostering self-regulated learning among learners. A meta-analysis on intervention studies at primary and secondary school level. Metacogn. Learn., 3, 231-264. 
Djaouti, D., Alvarez, J., \& Jessel, J. P. (2011). Classifying serious games: The G/P/S model. In P. Felicia (Ed.), Handbook of research on improving learning and motivation through educational games: Multidisciplinary approaches (pp. 118-136). Hershey: IGI Global.

Duffy, T. M., \& Jonassen, D. H. (Eds.). (2013). Constructivism and the technology of instruction: A conversation. Abingdon: Routledge.

Ennis, R. H. (1987). A taxonomy of critical thinking dispositions and abilities. In J. B. Baron \& R. J. Sternberg (Eds.), Teaching thinking skills: Theory and practice (pp. 9-26). New York: Freeman.

Facione, P. A. (1990). Critical thinking: A statement of expert consensus for purposes of educational assessment and instruction. California: California Academic press.

Facione, P. A. (2000). The disposition toward critical thinking: Its character, measurement, and relationship to critical thinking skill. Informal Logic, 20(1), 64-65.

Facione, P. A. (2009). Critical thinking: What it is and why it counts Retrieved from www.insightassessment.com/pdf_files/what\&why98.pdf. Facione, P. A. (2011). Think critically. Boston: Prentice Hall.

Fahim, M., \& Shakouri, N. (2012). Critical thinking in higher education. A pedagogical look. Theory and Practice in Language Studies, 2(7), 1370-1375

Finlay, L. (2008). Reflecting on 'reflective practice'. In Practice-based professional learning paper 52. Melton Keynes: The Open University.

Grand, S. (2003). Creation: Life and how to make it. Cambridge: Harvard University Press.

Grand, S. (2004). Moving Al out of its infancy: Changing our preconceptions. IEEE Intell. Syst., 19(6), 74-77.

Grand, S. (2005). Growing up with Lucy. Limited: Weidenfeld \& Nicolson.

Grand, S., \& Cliff, D. (1998). Creatures: Entertainment software agents with artificial life. Auton. Agent. Multi-Agent Syst., 1(1), 39-57.

Halpern, D. F. (1998). Teaching critical thinking for transfer across domains: Dispositions, skills, structure training, and metacognitive monitoring. The American Psychologist, 53(4), 449-455.

Halpern, D. F. (2003). Thought and knowledge: An introduction to critical thinking (4th ed). Mahwah, NJ: Erlbaum.

Harford, J., \& MacRuairc, G. (2008). Engaging student teachers in meaningful reflective practice. Teach. Teach. Educ., 24(7), 1884-1892.

Howard, T. C. (2003). Culturally relevant pedagogy: Ingredients for critical teacher reflection. Theory Pract., 42(3), 195-202.

Hughes, W., \& Lavery, J. (2015). Critical thinking: An introduction to the basic skills (7th ed.). Peterborough: Broadview press.

James, H. A., Scogings, C., \& Hawick, K. A. (2004). A framework and simulation engine for studying artificial life.

Kadleček, D., \& Nahodil, P. (2001). New hybrid architecture in artificial life simulation. In European conference on artificial life (pp. 143-146). Berlin, Heidelberg: Springer.

Kember, S. (2003). Cyberfeminism and artificial life. Abingdon: Routledge.

Kennedy, M. (1991). Critical thinking: Literature review and needed research. Educational values and cognitive instruction: Implications for reform, 2, 11-40. Hillsdale, NJ: Erlbaum.

Killen, R. (2015). Teaching strategies of quality teaching and learning (2nd ed.). Cape Town: Juta.

Kirby, S. (2002). Natural language from artificial life. Artificial Life, 8(2), 185-215.

Kirschner, P. A., Sweller, J., \& Clark, R. E. (2006). Why minimal guidance during instruction does not work: An analysis of the failure of constructivist, discovery, problem-based, experiential, and enquiry based teaching. Educ. Psychol., $41,75-86$.

Kompf, M., \& Bond, R. (2001). Critical reflection in adult education. In T. Barer-Stein \& M. Kompf (Eds.), The craft of teaching adults (pp. 21-38). Toronto: Irwin.

Langton, C. G. (1997). Artificial life: An overview. Cambridge: Mit Press.

Lugmayr, A., Sutinen, E., Suhonen, J., Sedano, C. I., Hlavacs, H., \& Montero, C. S. (2017). Serious storytelling-a first definition and review. Multimed. Tools Appl., 76(14), 15707-15733.

Mezirow, J. (1998). On critical reflection. Adult Educ. Q., 48(3), 185-198.

Neisser, U. (2014). Cognitive psychology: Classic edition. London: Psychology Press.

Norris, S. P., \& Ennis, R. H. (1989). Evaluating critical thinking. Pacific Grove: Critical Thinking Press Software.

Pavlov, I. P., \& Anrep, G. V. (2003). Conditioned reflexes. Chelmsford: Courier Corporation.

Perkins, D. N., \& Salomon, G. (1992). Transfer of learning. International Encyclopaedia of Education, 2, 6452-6457.

Pho, A., \& Dinscore, A. (2015). Game-based learning. Tips and trends. Washington DC: Spring Publications.

Piaget, J. (2013). The construction of reality in the child. Abingdon: Routledge.

Powell, K. C., \& Kalina, C. J. (2009). Cognitive and social constructivism: Developing tools for an effective classroom Retrieved from https:/www.questia.com/library/ journal/1G1-216181184/cognitive-and-social-constructivism-developing-tools,

Profetto-McGrath, J. (2003). The relationship of critical thinking skills and critical thinking dispositions of baccalaureate nursing students. J. Adv. Nurs., 43(6), 569-577.

Reynolds, M. (2011). Critical thinking and systems thinking: Towards a critical literacy for systems thinking in practice. In C. P. Horvath \& J. M. Forte (Eds.), Critical thinking (pp. 37-68). New York: Nova Science Publishers.

Ruger, H. A. (1910). The psychology of efficiency: An experimental study of the processes involved in the solution of mechanical puzzles and in the acquisition of skill in their manipulation. Canberra: Science Press.

Schön, D. (1983). The reflective practitioner. 1983. London: Maurice Temple Smith Ltd.

Schwartz, D. L., Bransford, J. D., \& Sears, D. (2005). Efficiency and innovation in transfer. Transfer of learning from a modern multidisciplinary perspective. Greenwich: Information Age Publishing.

Sinclair, K. (1998). Reflective practice in health care. In J. Creek (Ed.), Occupational therapy: New perspectives. London: Whurr Publishers.

Skinner, B. F. (2011). About behaviourism. New York: Vintage.

South African Institute for Distance Education. (2012). Getting practical. A guide to teaching and learning (3rd ed.). Cape Town: Oxford University Press.

Stupnisky, R. H., Renaud, R. D., Daniels, L. M., Haynes, T. L., \& Perry, R. P. (2008). The interrelation of first-year college students' critical thinking disposition, perceived academic control, and academic achievement. Res. High. Educ., 49(6), 513-530.

Tillema, H. H. (2000). Belief change towards self-directed learning in student teachers: Immersion in practice or reflection on action. Teach. Teach. Educ., 16(5-6), 575-591. 
Tobias, S., \& Duffy, T. M. (Eds.). (2009). Constructivist instruction: Success or failure? London: Routledge.

Trybus, J. (2010). Game-based learning: What it is, why it works, and where it's going. NMI White Paper. New York: New Media Institute.

Vygotsky, L. S. (1980). Mind in society: The development of higher psychological processes. Harvard: Harvard University Press.

Walkington, J., Christensen, H. P., \& Kock, H. (2001). Developing critical reflection as a part of teaching training and teaching practice. Eur. J. Eng. Educ., 26(4), 343-350.

Watson, J. B. (2013). Behaviourism. Worcestershire: Read Books Limited.

Willingham, D. T. (2008). Critical thinking: Why is it so hard to teach? Art Education Policy Review, 109(4), 21-32.

Woolfolk, A. E. (2010). Educational psychology: Modular active learning edition, student value edition. Prentice Hall.

Yang, S. H. (2009). Using blogs to enhance critical reflection and community of practice. Educational Technology \& Society, 12(2), 11-21.

Publisher's Note

Springer Nature remains neutral with regard to jurisdictional claims in published maps and institutional affiliations.

Submit your manuscript to a SpringerOpen ${ }^{\odot}$ journal and benefit from:

- Convenient online submission

- Rigorous peer review

- Open access: articles freely available online

- High visibility within the field

- Retaining the copyright to your article

Submit your next manuscript at $\boldsymbol{\nabla}$ springeropen.com 